\title{
Empathy among Medical Students Studying Different Curricula: A Comparative Study
}

Shezadi Sabah Imran*, Ariba Umer, Asifa Khan, Bushra Bibi, Aqsa Zainab, Anam Rahim

\section{ABSTRACT}

Objective: To determine and compare empathy among medical students, studying two different curricula.

Study Design: Cross Sectional.

Place and Duration of Study: The study was carried out at the Department of Community Medicine of Wah Medical College, Wah Cantt from January 2018 to June 2018.

Materials and Methods: The study was carried out on second and fourth year MBBS students. The sample size was 90, calculated by Open Epi calculator and the students were selected by using stratified random sampling technique. A data collection tool comprised of two parts; demographic information about the individual was collected in the first part and second part was based on Toronto Empathy Questionnaire. The questionnaire had 16 questions and scored between 0-64. The questions were responded on a Likert scale of never, rarely, sometimes, often and always. The data was analyzed by using software program of SPSS version 20. Descriptive statistics and Mann-Whitney $U$ test was applied to compare the mean scores of empathy of students studying different curricula.

Results: Mean score of empathy among students was $42.89 \pm 8.535$. Mean empathy score of $2^{\text {nd }}$ year students was $45.58 \pm 7.203$ and $4^{\text {th }}$ year students came out to be $40.20 \pm 8.981$. Empathy was statistically significant in $2^{\text {nd }}$ year students and in female students; female students' empathy score was 46.38 while male students score was 39.40.

Conclusion: It is concluded that $2^{\text {nd }}$ year students who studied integrated curriculum showed higher empathy scores than $4^{\text {th }}$ year students studying traditional curriculum. Moreover, female students showed significantly higher empathy scores as compared to the male students.

\section{Key Words: Cross-sectional Study, Empathy, Medical Students.}

How to cite this: Imran SS, Umer A, Khan A, Bibi B, Zainab A, Rahim A. Empathy among Medical Students Studying Different Curricula: A Comparative Study. Life and Science. 2021; 2(4): 169-172. doi: http://doi.org/10.37185/LnS.1.1.172

This is an Open Access article distributed under the terms of the Creative Commons Attribution License (http://creativecommons.org/licenses/by/4.0), which permits unrestricted use, distribution, and reproduction in any medium, provided the original work is properly cited.

\section{Introduction}

Empathy is to feel what another person is experiencing. It has been evident that empathy among the practitioners can reduce patient's risk, improve patient's health, allay anxiety among patients and increase compliance of patients and thus improve outcome. ${ }^{1,2}$ Empathy is very much linked with good social and interpersonal

Department of Community Medicine

Wah Medical College, Wah Cantt

Correspondence:

Dr. Shezadi Sabah Imran

Professor, Community Medicine

Wah Medical College, Wah Cantt

E-mail: sabah_imran00@yahoo.com

Funding Source: NIL; Conflict of Interest: NIL

Received: Oct 19, 2020; Revised: Mar 11, 2021

Accepted: Sep 07, 2021

169 relationship. ${ }^{3}$ In medical education, empathy is considered to be an essential professional attribute for clinicians therefore enhancement of empathy among medical students is an aim of medical education.

Doctor patient relationship is a vital component of physician work and this relationship depends on number of factors like communication skills, ability to understand patient's perspective and empathic attitude. If a doctor fails to understand patient's point of view or if he does not show empathy then the patients will be dissatisfied and his trust on doctor affected. ${ }^{4-6}$

Literature shows that with increasing years of medical education, empathy is diminishing among students which may affect the quality of health care. ${ }^{4}$ while some studies are not in favor of the hypothesis 
that increasing in years of education causes decrease empathy among medical students. ${ }^{7}$

A study, to assess students' perception about the factors that promote the development of empathy among students revealed that early contact of students with patients and training in professionalism and communication skills help in increasing empathy among them. ${ }^{8}$

Recently there is shift of medical education, traditional curriculum is now replaced with integrated curriculum in which students are exposed to the patients from the first year of medical education. Moreover, teaching of medical ethics and professionalism is started from the first year of their training. Empathy is an important topic to be taught in medical schools as it not only increases their interpersonal relationships but it also makes patients comfortable and satisfied. The present study was conducted with an aim, to compare empathy among students studying two different curricula and to ascertain the gender difference regarding empathy. It was hypothesized that students who have studied integrated curriculum are more empathic than those of conventional or traditional curriculum.

\section{Materials and Methods}

The study design was cross-sectional, carried out at the Department of Community Medicine, Wah Medical College from January 2018 to June 2018. The sample size was 90 , calculated by Open epi version 3 ; the confidence Interval was taken as $95 \%$, Power $90 \%$ and ratio of sample was 1 . Mean and standard deviations used for calculating sample size were $44.2 \pm 6.59$ and $39.7 \pm 6.54$. $^{9}$ As the ratio was one, sample size was distributed in two equal groups The sample was selected by using stratified sampling technique, 45 students from Second year MBBS studying integrated curriculum and 45 students from Fourth year MBBS who were taught traditional curriculum. A pre-designed validated structured questionnaire was used for collection of data and confidentiality and anonymity were maintained at all the times during the study. The first part of the questionnaire included demographic information and second part was based on Toronto Empathy Questionnaire. The questionnaire had 16 questions and scored between 0-64. The Cronbach alpha reliability of the questionnaire was $0.85 .^{10}$ The questionnaires were filled by the students themselves and empathy questions were responded on a Likert scale of never, rarely, sometimes, often and always, scoring $0-4$ on items $1,3,5,6,8,9,13$ and 16 while items $2,4,7,10,11,12,14$ and 15 scored reversely. The total score was calculated of each respondent. Data was analyzed by using software program of SPSS version 20, descriptive statistics including frequency of gender, use of social network, working status of mother, family income and mean scores of empathies were reported. Mann Whitney $U$ test was applied on mean scores of empathies of the two groups studying different curricula and also on mean empathy scores of male and female students at $p$ value of less than 0.05 .

\section{Results}

The study was carried out on 90 medical students, 45 each from second year studying integrated curriculum and from fourth year enrolled in traditional curriculum. The descriptive statistics of qualitative variables are presented in Table 1.

\begin{tabular}{|c|c|c|c|}
\hline \multirow{3}{*}{1} & \multicolumn{2}{|l|}{ Variables } & \multirow{2}{*}{$\begin{array}{c}\text { Frequency with } \\
\text { percentages } \\
80(89 \%)\end{array}$} \\
\hline & $\begin{array}{l}\text { People with } \\
\text { whom student }\end{array}$ & $\begin{array}{l}\text { Mother and } \\
\text { father }\end{array}$ & \\
\hline & grow & Father only & $6(7 \%)$ \\
\hline \multirow{4}{*}{2} & & Mother only & $3(3 \%)$ \\
\hline & & Others & $1(1 \%)$ \\
\hline & \multirow{2}{*}{$\begin{array}{l}\text { Involvement in } \\
\text { online social } \\
\text { network }\end{array}$} & No & $12(13.3 \%)$ \\
\hline & & Yes & $78(86.7 \%)$ \\
\hline \multirow[t]{2}{*}{3} & \multirow{2}{*}{$\begin{array}{l}\text { Working status } \\
\text { of mother }\end{array}$} & House wives & $60(66.7 \%)$ \\
\hline & & $\begin{array}{l}\text { Working } \\
\text { women }\end{array}$ & $30(33.3 \%)$ \\
\hline \multirow[t]{3}{*}{4} & \multirow{3}{*}{$\begin{array}{l}\text { Family income } \\
\text { of students }\end{array}$} & $<50,000$ & $12(13.3 \%)$ \\
\hline & & $50,000-100000$ & $38(42.2 \%)$ \\
\hline & & $>100000$ & $40(4.4 \%)$ \\
\hline
\end{tabular}

Mean scores of empathy among students was 42.89 and standard deviation was 8.535 and its distribution is shown in Figure 1.

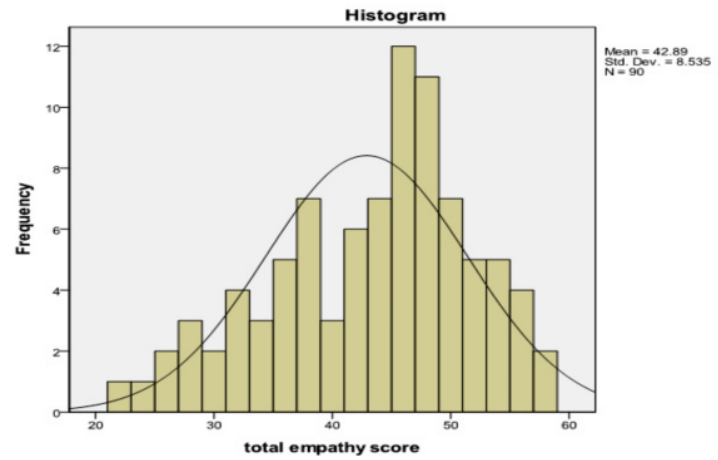

Fig 1: Distribution of Total Empathy score of students 
Mann Whitney $U$ test was applied on mean empathy scores of two different years of medical education studying different curricula and also on male and female students which showed significant difference at $p$ value of 0.05 . The results are presented in Table 2 and 3.

Table: 2 Mann Whitney U Test on Mean Empathy Score of Students Studying Different Curricula

\begin{tabular}{|c|c|c|c|c|}
\hline S.No & $\begin{array}{l}\text { Type of } \\
\text { curriculum }\end{array}$ & $\begin{array}{l}\text { Mean } \\
\text { score }\end{array}$ & $\begin{array}{l}\text { Standard } \\
\text { deviation }\end{array}$ & $P$ value \\
\hline 1 & Integrated & 45.58 & 7.203 & 0.003 \\
\hline 2 & Traditional & 40.20 & 8.981 & \\
\hline \multicolumn{5}{|c|}{$\begin{array}{l}\text { Table 3: Mann Whitney U test on mean Empathy scores of } \\
\text { male and female students }\end{array}$} \\
\hline S.No & $\begin{array}{l}\text { Gender of } \\
\text { students }\end{array}$ & $\begin{array}{l}\text { Mean } \\
\text { score }\end{array}$ & $\begin{array}{l}\text { Standard } \\
\text { deviation }\end{array}$ & $P$ value \\
\hline 1 & Male & 39.40 & 8.508 & \\
\hline 2 & Female & 46.38 & 7.075 & $<0.001$ \\
\hline
\end{tabular}

\section{Discussion}

In medical education, empathy is considered to be an essential professional characteristic for clinicians. The link between doctors and patients depend upon compassionate behavior, communication skills, knowledge and intention of the doctor to help the patient in every possible way. This relationship is very important for the management of patients therefore, it is one of the needs of medical education that students should be trained enough on communication skills, empathy and professionalism. The college was in transition phase and at a time both types of teaching, integrated and traditional, were carried out so it was planned to assess empathy levels among students studying two different curricula. The students of second year were taught separate course of professionalism, ethics and empathy while it was not imparted to the fourthyear students. The mean empathy scores of all students was found out to be 42.89 , which is low. The result was comparable with a study carried out by Nazish et al in two different institutions of Lahore, Pakistan which also concluded that mean empathy scores of students from two different institutions were low as compared to the previous literature. ${ }^{11}$ In our study the second-year students studying integrated curriculum showed higher level of empathy as compared to the fourth-year students. Similar results were reported by other studies showed that students who studied integrated curriculum showed higher level of empathy., ${ }^{9,12}$

Another important finding of our research was decreasing empathy scores with increasing time spent in medical education as fourth year students showed less empathy. This finding was supported by Mahoney et $\mathrm{al}^{4}$, Chen et $\mathrm{al}^{13}$ and Dongju et al. ${ }^{14}$ The results of these studies showed that the students who were in later years of education showed less empathy as compared to those who were in initial years of medical education. Few studies showed contradictory results, Magalhaes et alconcluded that final year students showed more empathy ${ }^{15}$ while Tariq et al found no effect of duration of medical education on empathy of students. ${ }^{16}$

The mean empathy scores of students studying integrated curriculum was significantly more as compared to the students exposed to traditional curriculum. Literature also support the role of teaching professionalism, empathy, ethics and communication skills by different means of teaching. Those students who had been taught these disciplines showed higher empathy which is very essential for gaining trust and confidence of patients. $^{6,17,18}$

Our study also showed that female students had higher empathy scores than male students Higher empathy levels in females is also supported by a study conducted by Hojat et $\mathrm{al}^{19}$, Helena et $\mathrm{al}^{20}$ and Thema et $\mathrm{al}^{21}$ while few studies found no difference in empathy scores related to gender. ${ }^{22,23}$ The reason of this difference might be due to nature of females as they have stronger sense of caring for other people, they can provide emotional support to others and they tend to show more social sensitivity and care oriented attitudes.

There are some limitations of the study, the sample size is small and other factors affecting empathy should also be identified. This study will help in modifying the curriculum and bring change in students' behavior and attitude.

\section{Conclusion}

It is concluded that mean empathy among students is low. The students enrolled in integrated modular curriculum has shown comparatively higher empathy scores than students studying conventional or traditional system. Moreover, female students showed significantly higher scores. 


\section{Recommendations}

Based on the study it is concluded that teaching empathy, medical ethics and professionalism play vital role in the development of empathy among students. So, in addition to routine lectures counseling sessions about human attitude, behavior and emotions should be arranged focusing more on male students and it must be ensured that the students should spend more time with patients as this can inculcate more empathy among them.

\section{REFERENCES}

1. Howick J, Steinkopf L, Ulyte A, Roberts N, Meissner K. How empathic is your health care practioner? A systematic review and meta-analysis of patient surveys. BMC Med Educ. 2017; 17: 136.

2. Loffer-Stastka H, Datz F, Parth K, Preusche I, Bukowski X, Seidman C. Empathy in psychoanalysis and Medical Education-what can we learn from each other? BMC Med Edu. 2017; 17: 74.

3. Jeon J, Kim S, Chon WH, Ha JH. Is internet over use associated with impaired empathic ability in Korean college students? Medicine (Baltimore). 2018; 97: e12493.

4. Mahoney S, Sladek RM, Nelid T. A Longitudinal study of empathy in pre-clinical and clinical medical students and clinical supervisors. BMC Med Educ. 2016; 16: 270.

5. Colliver JA, Conlee MJ, Verhulst SJ, Dorsey JK. Reports of the decline of Empathy During Medical Education Are Greatly Exaggerated: A Reexamination of the Research. Acad Med. 2010; 85: 588-93.

6. Hausberg $M C$, Hergert $A$, Kroger $C$, Bullinger $M$, Rose $M$, Andreas S. Enhancing medical students' communication skills: development and evaluation of an undergraduate training program. BMC Med Educ. 2012; 12: 16.

7. Ferreira-Valente A, Monteiro JS, Barbosa RM, Salgueira A, Costa P, Costa MJ. Clarifying changes in students empathy through in medical school: a scoping review. Adv Health Sci Edu. 2017: 22: 1293-1313

8. Pohontsch NJ, Stark A, Ehrhardt M, Kotter T, Scherer M. Influences on students' empathy in medical education: an exploratory interview with medical students in their third and last year. BMC Med Educ. 2018; 18: 231.

9. Ayub A, Khan AR. Measuring empathy of medical students studying in different curricula; a causal comparative study. J Pak Med Assoc. 2017; 67: 1238-41.

10. Spreng RN, McKinnon MC, Mar RA, Levine B. The Toronto
Empathy Questionnaire: Scale development and initial validation of a factor-analytic solution to multiple empathy measures. J. Pers. Assess. 2009; 91: 62-71.

11. Imran N, Aftab MA, Haider II, Farhat A. Educating tomorrow's doctors: A cross sectional survey of emotional intelligence and empathy in medical students of Lahore. Pak J Med Sci. 2013; 29: 710-4.

12. Ozcan $\mathrm{CT}$, Öksüz $\mathrm{E}$, Oflaz $\mathrm{F}$. Improving empathy in nursing students: a comparative longitudinal study of two curricula. J Korean Acad Nurs. 2018; 48: 497-505.

13. Chen D, Lew R, Hershman W, Orlander J. A cross-sectional measurement of medical student empathy. J Gen Intern Med. 2007; 22: 1434-8.

14. Li D, Xu H, Kang M, Ma S. Empathy in Chinese eight-year medical program student: differences by school year, educational stage, and future career preference. BMC Med Educ. 2018; 18: 241.

15. Magalhaes $E$, Salgueira AP, Costa P, Costa MJ. Empathy in senior year and first year medical students: a crosssectional study. BMC Med Educ. 2011; 11: 52.

16. Tariq N, Tayyab A, Jaffery T. Differences in Empathy Levels of Medical Students Based on Gender, Year of Medical School and Career Choice. J Coll Physicians Surg Pak 2018; 28: 31013.

17. Williams B, Sadasivan S, Kadirvelu A, Olaussen A. Empathy levels among first year Malaysian medical students: an observational study. Adv Med Educ Pract. 2014; 5: 149-56.

18. Batt-Rawden SA, Chisolm MS, Anton B, Flickinger TE. Teaching empathy to medical students: an updated, systemic review. Acad Med. 2013; 88: 1171-7.

19. Hojat M, Gonnella JS, Mangione S, Nasca TJ, Veloski JJ, Erdmann JB, et al. Empathy in medical students as related to academic performance, clinical competence and gender. BMCMed Educ. 2002; 36; 522-7.

20. Paro HB, Silveira PS, Perotta B, Gannam S, Enns SC, Giaxa RR, et al. Empathy among Medical Student: Is There a Relation with Quality of Life and Burnout? PLoS One. 2014; 9: e94133.

21. Quince TA, Kinnersley $P$, Hales J, Da Silva A, Moriarty $H$, Thiemann $P$, et al. Empathy among undergraduate medical students: A multi-centre cross-sectional comparison of students beginning and approaching the end of their course. BMC Med Educ. 2016; 16: 92.

22. Khan MA, Niazi IM, Rashdi A. Emotional Intelligence predictor of empathy in medical students. Rawal Medical Journal. 2016; 41: 121-4.

23. Hong M, Lee WH, Park JH, Yoon TY, Moon DS, Lee SM, et al. Changes of empathy in medical college and medical school: 1-Year follow up study. BMC Med Edu. 2012; 12: 122. 